\title{
Rights and the post-Brexit agenda: rights protection and institutional inadequacy in the United Kingdom
}

\author{
RUSSELL SOLOMON \\ RMIT University, Australia
}

russell.solomon@rmit.edu.au

\begin{abstract}
The issue of protection of rights in a post-Brexit UK has been largely absent from either the final rounds of EU/UK negotiations or the internal UK debate, other than in regard to Northern Ireland and citizen rights. The UK will leave the EU with little certainty as to how various rights, now 'brought home', will be protected and enforced. The protection of rights in the UK has been dependent on a multi-layered framework including EU institutions. The UK's withdrawal from the EU will produce gaps in this overall institutional framework. Rights protection is likely to be further diluted through Brexit's unsettling of the UK's constitutional arrangements within its current rights-averse political environment. This article adopts an institutional approach to assess the implications of Brexit for the $U K$ 's protection of rights. It argues that even with some regulatory alignment between the EU and the $U K$, inadequate institutional arrangements risk undermining current levels of protection.
\end{abstract}

Key words: Brexit, constitutionalism, devolution, institutional framework, rights

\section{Introduction}

As of January 2021, the United Kingdom (UK) has finally left the European Union (EU) after what seems to have been a protracted four and a half years. To the relief of many the departure came with a trade and cooperation deal, ${ }^{1}$ albeit one generally described as thin. The final set of negotiations was, not surprisingly, focused on certain trade issues, but 'level playing field', governance and dispute resolution matters were also discussed 'down to the line'. In the final round of negotiations, rights were only considered indirectly in terms of the 'level playing field' with citizens' rights having been the subject of earlier negotiations, thanks largely to the interest of the EU.

As the UK moves into the post-Brexit era, serious questions need to be asked about the nature and level of rights protection that is available in a UK now outside of the EU. The embeddedness of EU law in UK domestic law as a result of the 47 years of engagement has had a profound impact in both broadening the scope of rights and in making them more enforceable against both state and private actors. The successful Leave campaign, fuelled by the Eurosceptic media view that the EU's freedom of movement opened the floodgates to mass immigration from across Europe, had demonised human rights through its linkage to European courts. This skewed view of rights was bolstered by the failure of both Conservative and Labour governments to

\footnotetext{
${ }^{1}$ European Commission, 2020.
} 
support the EU, its European Convention on Human Rights (ECHR) and the UK's more recent Human Rights Act 1998 (HRA).

It is arguably the case that political actors in the UK have actively inhibited the promotion and protection of rights for its citizens (Gearty, 2016). Nevertheless, the role played by particular political actors is not sufficient to explain the challenge to rights protection in a post-Brexit UK. This article argues that the nature of the UK's protection of rights after Brexit can be best explained by reference to the nature of its own enduring though inadequate institutional framework. An institution is understood, adopting March and Olsen's broad definition, to be:

'a relatively enduring collection of rules and organized practices, embedded in structure of meaning and resources that are relatively invariant in the face of turnover of individuals and relatively resilient to the idiosyncratic preferences and expectations of individuals and changing external circumstances' (March \& Olsen, 2006, p.3).

Brexit has resulted in the removal of an important layer of protection, derived from EU institutional engagement, from the UK's multi-layered framework of rights protection. The article will initially consider the UK's institutional framework, including what the EU institutions have offered towards rights protection. It will then consider the impact of the loss of EU protections followed by a discussion of the variable risk profile offered by Brexit for three important areas of rights.

\section{The UK's political constitution and its approach to protecting rights}

The UK's ratification of international human rights treaties also requires domestic implementation through legislation for obligations to be enforceable. Without this, international legal obligations are of limited practical benefit for those alleging rights violations. With only some international obligations having otherwise been brought into domestic law, the removal of a layer of protection provided by EU law will mean a change in the types of adjudication, enforcement and routes to a remedy for those seeking redress in the UK. What will be the obligations of duty bearers in the UK, such as public authorities, how should they carry out their responsibilities and what remedies will be available for rights violations?

The UK's unwritten constitution ${ }^{2}$ has been described, often in flattering terms, as an evolving or flexible one. It is a political constitution with unclear legal content, assumptions and expectations. In contrast to written constitutions in similar liberal democracies, the UK's unwritten one does not give the judiciary the role of primary guardian of the constitutional order. The constitutional design and the history of the UK's engagement with human rights in the postwar period can be seen as providing a secure location for certain rights (Oliva, 2019, p.586). However, this is arguably an optimistic prognosis as to the protection, enforcement and promotion of rights once the EU's layer of protection is removed from the UK's institutional framework.

\footnotetext{
${ }^{2}$ In Robert Blackburn's words, the UK has 'a constitution, but it is one that that exists in an abstract sense, comprising a host of diverse laws, practices and conventions that have evolved over a long period of time' (Blackburn, 2015).
} 
At the centre of the UK's constitutional framework is the parliament at Westminster and the notion of parliamentary sovereignty. The dominant view remains that articulated by A.V. Dicey ${ }^{3}$ that no institutions can overrule parliament. In effect, this means that there is no distinction between constitutional and 'normal' statute law. This doctrine of parliamentary sovereignty understandably sat awkwardly with the direct effect and supremacy of EU law which could result in UK law being disapplied if considered to have breached rights as identified by the European Court of Justice (CJEU). The doctrine was mythologised by both Conservative and Labour parties for their own purposes while each failed to own up to their involvement, while in government, in shaping EU policies (Lord, 2019, p.294). Adherence to this doctrine also fed the scepticism about the UK's engagement with the EU around rights and contributed to both the Leave campaign's and Conservative governments' view that the EU's legal protection of rights was foreign and that rights should be 'brought home'.

The primacy of parliament within the UK's constitutional settlement was reaffirmed in the two Miller cases of $2017^{4}$ and $2019^{5}$. In the first case, the Supreme Court confirmed that it was the role of parliament and not the executive to formally withdraw the UK from the EU while, in the second case, Prime Minister Johnson's proroguing of parliament was seen as a device to avoid parliamentary scrutiny over the Brexit process. This judicial support for the doctrine is arguably a traditional constitutional one for the courts (Ewing, 2017, p.724) that reveals the deferential nature of the UK courts to the parliament and, indirectly, a wariness of European legal constitutionalism. The UK courts reconciled their support for parliamentary sovereignty with the accommodation of the EU supremacy principle by seeing the domestic effect of EU law as a function of domestic law (Elliott, 2020a, p.3). The 'taking back control' mantra of both the Leave campaign and the Conservative government has been loosely interpreted as being about the promotion of parliamentary sovereignty, at least at Westminster if not for the regional legislatures. The history of the Brexit process within the UK from mid-2016 to early 2020 revealed a struggle between the parliament and the executive with the judiciary supporting parliament. The end result of the process of 'returning sovereignty' has paradoxically seen the executive rather than parliament emerge as dominant thanks to the government's landslide election win of December 2019.

Despite the accommodation of the UK courts, the UK's membership of the EU did alter the balance of power in the UK system of government in favour of the judiciary. Direct effect and supremacy of EU law served to limit the power of the UK parliament and, importantly, there was now judicial review of UK primary legislation where this had not existed before (Bogdanor, 2018, p.78). The engagement with the EU's legal constitution over the 47 years of membership, through the conduit of the European Communities Act 1972 (UK), raises questions as to whether and what changes will remain in the UK's institutional arrangements once the UK departs the EU. At a minimum, when it comes to EU retained law as given under the European Union (Withdrawal) Act 2018 (UK) (EUWA), domestic UK courts can be expected to at least pay due regard to CJEU decisions.

\footnotetext{
${ }^{3}$ Dicey, A.V. (1915). Introduction to the Study of the Law of the Constitution.

${ }^{4} \mathrm{R}$ (on the application of Miller and another) v Secretary of State for Exiting the European Union [2017] UKSC 5.

${ }^{5} \mathrm{R} v$ The Prime Minister [2019] UKSC 41.
} 
The UK has made much of its tradition of common law rights but these are limited, primarily civil and political rights and not constitutionally entrenched as with rights in the legal constitutionalist systems of continental Europe. The common law in the UK is rather seen as being based on the notion of being flexible, responsive and pragmatically based and promoting a 'common sense' approach to rights (Jay, 2017, pp. 846, 847). Indeed, the limited nature of these rights was recognised by a former President of the UK Supreme Court who saw the idea of rights being determined by courts rather than parliament as being 'little short of offensive to [British] notions of constitutional propriety' (Neuberger, 2014, para 28).

\section{Impact of the loss of EU protections}

Brexit must inevitably affect governance and constitutional arrangements but it is far from certain what the full impact of Brexit will be on the protection of rights. The EU's progressive legal embedding within the UK can be seen as an important contributor to the protection of rights within the UK. It can be expected that the history of the EUUK relationship will have produced a certain path dependence ${ }^{6}$ in terms of how the UK's political and legal institutions will approach rights issues and their protection, at least in the early post-Brexit years. In terms of rights protection, the extent to which the UK institutions will continue to exhibit elements of their recent engagement with EU institutions will depend on a number of factors. It will partly depend on how closely aligned the UK will be to the EU in terms of its broader trade and economic relationship and be subject to EU conditionality. Also, it will depend on what other imperatives face the Johnson government, in particular getting the COVID-19 pandemic under control, as well as how effective civil society actors will be in advocating for the maintenance of current levels of rights protection.

An evaluation of rights protection in a post-Brexit UK requires a consideration of what is lost in terms of the EU layers of protection, whether this loss matters, and if so whether UK institutions are capable of addressing possible shortfalls in protection. The most important loss is the removal of the EU's Charter of Fundamental Rights of the European Union (the Charter) as provided for in the EUWA 2018. These fundamental EU rights now only serve in the interpretation of retained EU law. ${ }^{7}$ Under EU law, member states were also expected to ensure their domestic laws complied with a number of EU Directives setting out minimum standards, such as the Working Time Directive. These Directives, important as they are in bolstering rights in a number of social and economic areas, have automatically ceased to apply once the UK left the EU. Section 5(5) of EUWA 2018 provides for the retention of 'fundamental rights or principles which exist irrespective of the Charter' though it fails to specify them. While the Explanatory Notes ${ }^{8}$ accompanying the European Union (Withdrawal) Bill of 2018 downplayed the importance of the Charter, ${ }^{9}$ there is no doubt the breadth of its rights and their legally binding nature provided a higher level of protection than the UK's Human Rights Act 1998 (UK) (HRA) or the long-standing European Convention on Human Rights (ECHR).

\footnotetext{
${ }^{6}$ Path dependence is understood to mean that once a political entity takes a particular path the costs of reversal are very high and 'certain institutional arrangements obstruct an easy reversal' (Levi, 1997, p. 28).

${ }^{7}$ House of Commons. (2018). European Union (Withdrawal) Act 2018. Schedule 1, paragraph 4. Individuals will no longer be able to seek damages arising from the failure to effectively implement retained EU law.

${ }^{8}$ House of Commons. (2018). Explanatory Notes. European Union (Withdrawal) Bill 2018 (UK).

${ }^{9}$ The government also claimed that the Charter added little or nothing to existing rights protection: UK

Department for Exiting the European Union (2017).
} 
The Charter is both substantively and procedurally more important than the other rights instruments that will remain after the UK departure from the EU. It contains 50 rights, three times more than the ECHR and includes economic and social rights, civil and political rights as well as third generation fundamental rights such as guarantees concerning bioethics. While several rights are equally protected in the ECHR, it is in the Charter that they are given greater specificity with Charter rights having enjoyed the status of being EU mandated rights (Aronofsky, 2018, p.180). With the Charter it was the closest the UK had come to a codification of rights with a judicial review of primary legislation (Bogdanor, 2018, p.151). Other key differences include a free standing equality guarantee (Articles 20, 21) where, by contrast, the ECHR only protects against discrimination in the enjoyment of other rights; an express right to legal aid as necessary to ensure access to justice (Article 47); and an express right in the Charter to the protection of personal data (Article 8). European Court of Justice (CJEU) decisions added to these as with the case of an individual's 'right to be forgotten'. ${ }^{10}$

The Charter's role in providing institutional protection for rights in the UK was not just about the specificity of those rights but in also limiting parliamentary sovereignty and providing remedies for the violation of rights. Importantly, the Charter's removal means both reduced obligations upon the state and the loss of external oversight from the courts (Grogan, 2019, p.684). Once domestic remedies had been exhausted an individual could use the Charter to seek a binding judgment by way of a preliminary reference at first instance by the CJEU and then have that enforced in the UK. The closing of this avenue with the loss of the Charter is a significant loss for individual claimants. The HRA, in translating ECHR rights into UK domestic law, does not offer the same opportunity should one of its rights be violated and thereby limits the enforceability of these rights (Bogdanor, 2018, p.150).

The EUWA of 2018 produced another significant change to the institutional protection of rights in the UK with its use of 'Henry VIII clauses' to bring EU-retained law into UK law. This mechanism allows a wide Ministerial discretion to amend or repeal such transposed EU law and any associated UK law via secondary legislation and, even if greater parliamentary scrutiny later develops, the nature of this mechanism will mean such legislation will likely be open to fast-track executive action (O'Cinneide, 2018, p.5). Its operation undermines fundamental rights, is undemocratic and undermines parliamentary sovereignty (Douglas-Scott, 2015a) and, contrary to its aim, the mechanism fails to fully separate UK legislation from EU law nor does it provide the mooted legal certainty (Grogan, 2019, p.686).

The other principal instrument for the protection of human rights in the UK is the HRA which incorporates the rights of the ECHR. As a parliamentary bill of rights the HRA adopted the dialogue model and sought to strike a compromise between parliamentary sovereignty and the rule of law. If a right under the HRA is breached the court can make a declaration of incompatibility as to the offending statute though parliament can then ignore this finding. Without further recourse to the courts, the individual claiming the breach effectively has an unenforceable right. The difference between the

${ }^{10}$ Google Spain v Costeja Gonzalez [2014] Case C-131/12. 
consequences under the Charter and those under the HRA was well illustrated in the Benkharbouche case of 2015. ${ }^{11}$

The threat by then Prime Minister May in 2017 to repeal the HRA and replace it with a, presumably weaker, Bill of Rights was shelved until after Brexit. However, it is now a live issue with the UK having left the EU. With the HRA subject to the UK's political constitution and the judiciary unable to disapply a statute, the HRA may be safe from repeal or serious amendment. However, just as Brexit was partly seen as being about ending judicial supremacy through EU law and the influence of European courts so the HRA, in transposing ECHR rights and involving judicial consideration, remains a possible target.

Breaches of ECHR rights can eventually end up before the European Court of Human Rights (ECtHR) even after Brexit. However, given ECHR lacks an enforcement mechanism, such court decisions remain unenforceable in the UK. Not being a creature of EU law, the ECHR provides neither public enforcement for breaches by a state ${ }^{12}$ nor private enforcement and remains less entrenched within the UK legal order (Lock, 2017, p.17). With Brexit, it will also become easier for the UK to leave the ECHR as the European Commission could not then argue that this constitutes a breach of an EU treaty.

In its 2019 election manifesto, the Conservative party foreshadowed a Constitution, Democracy \& Rights Commission to 'update the HRA and administrative law to ensure.....a proper balance between the rights of individuals, our vital national security and effective government.' The manifesto stated that judicial review would be available to protect an individual's rights against an 'overbearing state' but not so as to 'conduct politics by another means or to create needless delays' (Conservative and Unionist Party, 2019, p.48). An independent panel was to consider judicial review in July $2020^{13}$ leading to possible changes to curb the courts' capacity to hold government to account and uphold the rule of law (Elliott 2020b). As yet, no changes have been announced. However, given the absence of legal-constitutional constraints, the current government, having received two recent adverse Supreme Court decisions, could be tempted to use primary legislation to 'settle the score' with the removal of the HRA as collateral damage.

The UK government obviously retains an interest in examining both the scope of rights protection available to individuals and what it identifies as excessive judicial power. In placing 'Dicey back on his pedestal' and taking advantage of its House of Commons majority to repeal the HRA and enact a weakened Bill of Rights, the government would almost certainly face challenges if it removes rights or freedoms either previously created by parliament or acknowledged by the common law (Ewing, 2017, p.725).

\footnotetext{
${ }^{11}$ Benkharbouche v Embassy of the Republic of Sudan; Janah v Lybia [2015] UWCA Civ 33. Claims based on the EU Working Time Regulations and racial discrimination based on domestic law implementing EU directives resulted in the UK Act being disapplied and making the defendants liable. On the hand, the plaintiffs' claims based solely on UK law only resulted in a declaration of incompatibility.

${ }^{12}$ As compared to that provided by Article 258 of the EU's Treaty on the Functioning of the European Union (TFEU).

${ }^{13}$ UK Ministry of Justice. (2020, July 31).
} 


\section{Devolution, rights and institutional complexity}

A recently established feature of the UK's complex constitutional settlement is the devolved competences of the regions of Scotland, Wales and Northern Ireland. The UK's membership of the EU has cut across the territorial distribution of powers between the UK and regional legislatures and the impact of Brexit upon rights will differ across these regions. The HRA is embedded in the devolved arrangements but the statutes enacting these arrangements differ across the regions. The institutional mechanism by which the UK parliament consults with the regional parliaments over these devolved responsibilities is the Sewel convention of 1998. As a political understanding rather than a legal convention ${ }^{14}$ the UK parliament has ignored it and avoided relinquishing any authority during the Brexit process.

The UK government chose not to consult with the regions during the Brexit process despite an early undertaking and this breakdown of 'constitutional comity' (Elliott, 2020a) revealed the Sewel convention to be little more than a 'self-serving ordinance' (Bogdanor, 2018, p.255). The regions' weak position was confirmed when Scotland, the strongest politically of the regions, sought to chart an independent course and retain the application of both Charter rights and the general principles of EU law to retained EU law. In the Scottish Continuity Bill case, ${ }^{15}$ the Supreme Court declared the UK institutions to be dominant in deciding the UK's departure as well as what happens to all functions and competences coming back to the UK, including those within devolved policy areas (Baroncelli \& Rosini, 2020, p.82).

Northern Ireland has been in a unique position, with the Good Friday Agreement (GFA) (or Belfast Agreement) of 1998 playing a critical role in rights protection and in bringing peace to Northern Ireland. The GFA was predicated on the UK remaining in the EU. The defeat of those seeking reunification of Ireland was 'masked in the language of victory on the human rights front' with its commitment to the ECHR (Gearty, 2016, p.183). The linkage between the HRA and the ECHR was recognised as important and the UK government committed itself to incorporate the ECHR into Northern Ireland law. Any move to repeal the HRA was likely to be seen as a breach of the GFA and thus a violation of an international treaty with the Irish Republic (McDonald, 2015). With the Northern Ireland Protocol ${ }^{16}$ to the European Union (Withdrawal) Act 2019 (UK), citizens of this region are uniquely placed in that they are eligible to be both UK and Irish citizens, and thus also EU citizens, though no longer entitled to Charter rights and remedies.

Most, but not all, ${ }^{17}$ human rights are within the competences of the regions and there is nothing to prevent them from providing enhanced protections or adding to the rights that currently exist. Thus a potential divergence in rights protection could emerge across the UK adding further statutory complexity. However, Brexit's removal of EU law will weaken the level of protection for specific rights while the UK Parliament could easily legislate to override any regional enhancements to rights.

\footnotetext{
${ }^{14}$ In the Miller case of 2017, the Supreme Court confirmed that the court could neither interpret nor enforce this convention.

${ }^{15}$ The UK Withdrawal from the European Union (Legal Continuity) (Scotland) Bill - A Reference from the Attorney-General and the Advocate-General for Scotland [2018] UKSC 64.

${ }^{16}$ UK Cabinet Office, 2020.

${ }^{17}$ Equality law is an important area of rights which remains reserved by the UK Parliament under the current devolution settlement.
} 


\section{Rights and their relative risk from Brexit}

An understanding of the adequacy of institutions to protect rights in a post-Brexit UK can be further explored through a discussion of the relative impact upon three important areas of rights: citizen rights, equality rights and workers' rights. Citizenship rights were of direct concern to many UK residents and were settled quite early in the negotiations given they were a 'red line' issue for the EU negotiators. With the departure of the UK from the EU, the parties agreed ${ }^{18}$ that while nothing will change for the 3.5 million EU citizens in the UK and the 1.5 million UK citizens in the EU27, they need to apply for a new residence status (settled status if five years spent in the UK or pre-settled status if less than five years) to prove their legal status. There are some restrictions on movement in terms of how long such persons can be outside either the UK or the EU country of residence without losing the status but otherwise, citizen rights remain as before Brexit. ${ }^{19}$ UK citizens resident in an EU27 country now face restrictions on moving beyond their resident country. Whether they can now live or work in another EU27 country will depend on what agreements the UK will make with that country.

Free movement for UK nationals into the EU and for EU citizens coming to live or work in the UK after Brexit is at an end. The latter group will now be subject to a pointsbased immigration system aimed at restricting immigration and preferencing skilled workers. ${ }^{20}$ The negotiations were conducted by the UK executive without consultation with parliament. They lacked focus, with the result being that the rights of UK citizens to live and work in other countries in the EU27 remains unsettled. These UK citizens thus remain as third country nationals subject to a patchwork of EU measures and national laws. For UK nationals travelling to the EU27, replacement arrangements for the loss of the European Health Insurance Card (providing access to medical care for Britons across the EU) are yet to be finalised.

The withdrawal agreement only settles residence and rights and applies the EU principle of equal treatment for a defined category of people while for others, this area of rights remains a complex and unsettled one. ${ }^{21}$ The position of family members and dependants of both EU citizens in the UK and of those UK citizens in the EU27 seeking to come to UK are two examples where greater clarity and expedited procedures are still required from the UK government. The CJEU retains interpretative authority as to citizens' rights for the first eight years after Brexit and UK courts can, though are not obliged, refer cases to the CJEU. Whatever the future mobility framework agreed by the EU and the UK, the loss of unlimited access for half a billion people in the EU and the UK has brought with it the end of free movement and the right to equal treatment (Barnard \& Leinarte, 2019, p. 152).

The Equality Act 2010 (UK) is the principal statute ${ }^{22}$ for the protection and promotion of equality rights in the UK. This progressive instrument is recognised as having

\footnotetext{
${ }^{18}$ European Union. (2019, October 17). Agreement on the withdrawal agreement of the United Kingdom of Great Britain and Northern Ireland from the European Union and the European Union Atomic Energy Community. Part Two. https://eur-lex.europa.eu/legal-content/EN/TXT/PDF/?uri=CELEX:12019W/TXT(o2)\&from=EN.

19 There is an exception for people moving between Ireland and the UK given their separate common travel area.

${ }^{20}$ HM Government. (2018, December).

${ }^{21}$ For example, the agreement covers only EU nationals who are living in the UK and vice versa at the time of the UK's withdrawal from the EU.

${ }^{22}$ There is also supplementary specific protection for particular groups such as with the Marriage (Same-Sex Couples) Act 2013 (UK).
} 
implemented EU law in the field of equality and anti-discrimination. The UK was a willing partner of the EU's Equality Framework ${ }^{23}$ that developed over the past two decades and, without denying the UK's own progress, EU law with its binding standards was 'the engine that has hauled the development of UK anti-discrimination law along in its wake' (O'Cinneide, 2016). While this Act does not face imminent dilution in a post-Brexit UK, it had been underpinned by the EU's General Principles, the Charter's Articles 20 and 21 and CJEU caselaw, all now no longer available.

The absence of CJEU influence will be the greatest loss for UK equality law, mainly in the areas of CJEU interpretations, along with the removal of the enhanced remedies available to the UK courts through the EU charter. ${ }^{24}$ With the EUWA of 2018 failing to preserve the existing scope and levels of protection beyond Brexit, reductions in equality standards could appear over time. Another weakness in the Equality Act of 2010 is that, contrary to EU law, discriminatory provisions are not unlawful if authorised by other primary or secondary legislation. Only 'due regard' to equality must be given in the drafting and interpretation of other statutes (Busby, 2017, 6). EUderived equality laws within secondary legislation, such as those providing for equal treatment as to working arrangements including equal pay, will be particularly vulnerable to dilution, if not removal, by the use of 'Henry VIII clauses' granting broad ministerial fiat. While judicial review of such regulatory instruments will potentially continue, this is not the same as redress previously available through the courts for breaches of Charter rights.

After Brexit, ECHR and HRA rights will undoubtedly continue to help address shortcomings in UK antidiscrimination laws despite being unable to prevent rightsincompatible anti-discriminatory laws. However, the UK equality regime will still be significantly weakened due to the loss of both enforcement remedies previously available under EU law and its broader scope covering economic and social rights. In post-Brexit UK, the common law also does not offer itself as an important alternative means by which to protect equality rights given its past ineffectiveness, explaining why statute-based equality law was developed in its place. As to the future, equality law is now largely in the hands of the UK parliament and it may be left to civil society groups to seek to both overcome any institutional blockages to promoting progressive equality programs and keep the UK closely aligned with developments in the EU.

Prior to Brexit, UK workers' rights had in recent years been supported by the Charter and the EU General Principles, in particular the Working Time Directive. Many employment-related rights derive directly from EU law including measures to prevent discrimination against part-time and temporary workers; protection for agency workers; paid holiday and working time; protection for employees when their roles are transferred from one employer to another; and parental leave rights (McColgan, 2016, p. 215).

The differing approach of EU and UK courts is another institutional factor which does not augur well for the interpretation of labour rights legislation post-Brexit. The CJEU has generally tended to give a wide meaning to social rights, interpret derogations strictly and pay greater attention to international treaties than the UK courts (Ford,

\footnotetext{
${ }^{23}$ The EU Equality Framework includes the Employment Equality Framework Directive (2000/78/EC), the Race Equality Directive (2000/43/EC) and the Equal Treatment Directive (2006/54/EC.

${ }^{24}$ One important influence of CJEU caselaw on UK equality law was the lifting of the compensation cap on discrimination claims, something now susceptible to reduction.
} 
2016, p. 404). The UK courts and their common law tradition have, instead, tended to give both greater attention to property and contractual rights than labour rights and more literal interpretations to legislation coming before them. With the loss of references to the CJEU may also come more procedural constraints, such as increasing the difficulties of bringing an action in the courts as well as exemptions for small businesses. The UK government will now be able to legislate to apply limits to any remedies available without having to be concerned about the CJEU constraining such action.

The EU-UK negotiations only indirectly addressed workers' rights and the final minimal Trade and Cooperation Agreement of December 2020 was only relevant in terms of what was agreed as to the 'level playing field'. The Agreement's 'nonregression clause' (Article 6.2) is important in that the UK is not permitted to reduce workers' rights below their current level, with breaches subject to arbitration. ${ }^{25}$ However the deal arguably shifts the protection of these rights from being about the protection of UK workers to being about the protection of European profits (MoyerLee, 2021). Early analysis of the deal considers that it could allow for these rights to be undermined through a process that sets a high bar for proving that the lowering of protections affects trade and investment, resulting in the probable rare enforcement of transgressions (Morris, 2020, p.7). ${ }^{26}$ Institutionally within the UK, the diminished influence of the trade union movement over recent decades will have weakened its general ability to challenge a possible lowering of labour protections by a UK government should it seek to take advantage of the deal (Jones, 2020).

\section{Concluding comments}

The UK's institutional framework for the protection of rights was a complex and multilayered one that had linked the EU's legal constitutionalism with the UK's own political constitution. This framework enabled individuals to secure redress against the state through the courts for violations of rights while facilitating engagement with rightspromoting developments, such as the EU's Equality Framework. Brexit's removal of the Charter as well as severely limiting the access to, and influence of, the European Court of Justice has negatively impacted both the range of substantive rights that can be protected and the procedural means by which to deliver their effective protection. The recent EU-UK Trade and Cooperation Agreement hardly addresses rights and the EU's focus has shifted squarely, as with the UK, to protecting its economic position rather more than its rights regime.

The post-Brexit framework is not so much about directly and explicitly removing certain rights from effective protection but rather leaves many questions unanswered as to what will replace the substantive and procedural rights removed by the EUWA of 2018 and 2019. The UK government's vague statements that rights protection will be unchanged lack transparency while also denying the reality that rights protection is now almost exclusively left in the political domain with its dominant political culture of majoritarianism. The current government's sizeable majority resulted in the executive's dominance of parliament as revealed by the removal of parliamentary

\footnotetext{
${ }^{25}$ Should the EU be successful at arbitration, the tariffs imposed could not be at a rate higher than necessary to rectify the distortions from the UK caused by the undercutting and thus, over time, the UK could still gain an advantage from reducing workers' rights.

${ }^{26}$ In the weeks immediately following Brexit, the UK government was reported to be planning to scrap the 48hour cap on the working week as well as other deregulatory measures (Middleton, 2021).
} 
scrutiny of the final Brexit negotiations in the EUWA 2019 and the neglect of the Sewel convention. The parliament has also been left with little voice as to how EU-retained law will be incorporated into domestic law while the UK courts' deferential approach to parliamentary sovereignty makes robust common law protection of rights unlikely.

The UK's planned reversion to its pre-existing institutional framework for the protection of rights is incomplete given the path dependency created by its historical engagement with the EU's legal entrenchment of rights and the changed expectations around the protection of rights. Given the different logics of the UK's framework based on parliamentary sovereignty and the EU's legal constitutionalism, the nature of this post-Brexit institutional accommodation is unclear. What is clear is that the reversion will mean a marginal role for the courts and that without some form of legalconstitutional constraint, rights protection could be amended, if not removed, by statute. With all the gaps and silences around rights that Brexit has created, it remains a matter of concern going forward as to how important the role of law and human rights norms, as drawn from both international and EU law, will be in the protection of rights in the UK.

\section{References}

Aronofsky, D. (2018). Brexit Human Rights Issues: It's Time to Play E.U. Hardball. Texas International Law Journal, 53(2), 177-210.

Barnard, C., \& Leinarte, E. (2019). Brexit and Citizens' Rights. European Journal of Legal Studies, Special Issue, October, 117-152. https://doi: 10.2924/EJLS.2019.005

Baroncelli, S., \& Rosini, M. (2020). Brexit, sovereignty and devolution: the view of constitutional law. In A. Bongardt, L.S. Talani, \& F. Torres (Eds.), The Politics and Economics of Brexit (pp. 56-87). Edward Elgar Publishing. https://doiorg.ezproxy.lib.rmit.edu.au/10.4337/9781788977975

Beale, K. (2016). The United Kingdom without the Charter of Fundamental Rights of the European Union: Putting Down the Dog That Did Not Bark? In P. Birkinshaw, \& A. Biondi (Eds.), Britain Alone! The Implications and Consequences of United Kingdom Exit from the EU (pp. 257-290). Wolters Kluwer.

Bellamy, R. (2007). Political Constitutionalism: A Republican Defence of the Constitutionality of Democracy. Cambridge University Press. https://doi-org.ezproxy.lib.rmit.edu.au/10.1017/CBO9780511490187

Blackburn, R. (2015, March 13). Britain's Unwritten Constitution. The British Library blog. https://www.bl.uk/magna-carta/articles/britains-unwritten-constitution

Bogdanor, V. (2018). Beyond Brexit: Towards a British Constitution. I.B. Tauris.

Boyle, K., \& Hughes, E. (2018). Identifying routes to remedy for violations of economic, social and cultural rights. The International Journal of Human Rights, 22(1), 43-69. https://doi.org/10.1080/13642987.2017.1390304

Busby, N. (2017). Equality law, Brexit and devolution. Greens Employment Law Bulletin, 142, 4-7. https://www.civilsocietybrexit.scot/wpcontent/uploads/sites/49/2019/12/EmpLB-Busby-article-I.142.pdf

Conservative and Unionist Party. (2019, December). Get Brexit done and unleash Britain's potential. Manifesto. 
Department for Exiting the European Union. (2017, December 5). Charter of Fundamental Rights of the EU Right by Right Analysis. Department for Exiting the European Union.

https://assets.publishing.service.gov.uk/government/uploads/system/uploads/attac hment data/file/664891/05122017 Charter Analysis FINAL VERSION.pdf

Dicey, A.V. (1915). Introduction to the Study of the Law of the Constitution. MacMillan.

Dickson, B. (2011). The Influence of European Law on the Protection of Fundamental Human Rights in United Kingdom Law. In P. Popelier, C. Van de Heyning, \& P. Van Nuffel (Eds.), Human Rights Protection in the European Legal Order: the Interaction between the European and the National Courts (pp. 343-363). Intersentia.

Douglas-Scott, S. (2015a, April 17). Constitutional Implications of a UK Exit from the EU: Some Questions That Really Must Be Asked. U.K. Constitutional Law Blog. http://ukconstitutionallaw.org

Douglas-Scott, S. (2015b). Fundamental Rights not Euroscepticism: Why the UK Should Embrace the EU Charter. In K.S. Ziegler, E. Wicks, \& L. Hodson (Eds.), The UK and European Human Rights: A Strained Relationship? (pp. 249-274). Hart Publishing.

Elliott, M., \& Thomas, R. (2017). Human rights as a constitutional pillar. In M. Elliott, \& R. Thomas (Eds.), Public Law ( $3^{\text {rd }}$ ed., pp. 759-815). Oxford University Press.

Elliott, M. (2020a, May 25). The United Kingdom's Constitution and Brexit: A ‘Constitutional Moment'? University of Cambridge Faculty of Law Research Paper No. 22/2020. University of Cambridge Faculty of Law. https://ssrn.com/abstract=3609965

Elliott, M. (2020b, November 23). The UK Constitution under pressure: A lost age of civility? Public Law for Everyone blog.

https://publiclawforeveryone.com/2020/11/23/the-uk-constitution-under-pressurea-lost-age-of-civility/

European Commission. (2020, December 24). Trade and Cooperation Agreement between the European Union and the European Atomic Energy Community and the United Kingdom of Great Britain and Northern Ireland. https://eur-lex.europa.eu/legalcontent/EN/TXT/PDF/?uri=CELEX:22020A1231(01)\&from=EN

Ewing, K.D. (2017). Brexit and Parliamentary Sovereignty. The Modern Law Review, 8o(4), 685-745. https://doi-org.ezproxy.lib.rmit.edu.au/10.1111/1468-2230.12281

Ford, M. (2016). The Effect of Brexit on Workers' Rights. King's Law Journal, 27(3), 398415. https://doi-org.ezproxy.lib.rmit.edu.au/10.1080/09615768.2016.1250477

Fredman, S., Young, A., \& Campbell, M. (2018, May 29). The continuing impact of Brexit on equality: the findings. Oxford Human Rights Hub and The UK in a Changing Europe. https://ukandeu.ac.uk/wp-content/uploads/2018/05/The-continuingimpact-of-Brexit-on-equality-rights-the-findings.pdf

Gallagher, C., Patrick, A., \& Byrne, K. (2018). Report on Human Rights Implications of UK withdrawal from the EU. An Independent Legal Opinion by Doughty Street Chambers. Commissioned by European United Left/Nordic Green Left Group of the European Parliament. http://www.guengl.eu/uploads/newsdocuments/GUE NGL Brexit and HR Final 020318 TO PRINT.pdf

Garcia Oliva, J. (2019). Brexit, Human Rights and the Role of Constitutional Culture. Revista de Investigações Constitucionais, 6(3), 573-594. http://dx.doi.org/10.5380/rinc.v6i3.70441 
Gearty, C. (2016). On Fantasy Island - Britain, Europe and Human Rights. Oxford University Press.

Gearty, C. (2019, August 8). She's dead of course! The British Constitution and Human Rights. LSE Brexit Blog. https://blogs.lse.ac.uk/brexit/2019/07/03/shes-dead-ofcourse-the-british-constitution-brexit-and-human-rights

Giannoulopoulos, D. (2017, November 9). EU citizens' rights and Brexit negotiations: both sides could be violating human rights law. The Conversation.

https://theconversation.com/eu-citizens-rights-and-brexit-negotiations-both-sidescould-be-violating-human-rights-law-87030

Gordon, M. (2016). Brexit: a challenge for the UK constitution, of the UK constitution? European Constitutional Law Review, 12(3), 409-444. https://doi.org/10.1017/S1574019616000298

Gordon, M. (2017). Brexit: the relationship between the UK parliament and the UK government. In M. Dougan (Ed.), The UK after Brexit. Legal and Policy Challenges (pp. 15-33). Intersentia. https://doiorg.ezproxy.lib.rmit.edu.au/10.1017/9781780685953

Grogan, J. (2019). Rights and Remedies at Risk: Implications of the Brexit Process on the Future Rights in the UK. Public Law, 683-702. https://uk.westlaw.com/Document/I15F34040D9FC11E99...

HM Government. (2018, December). The UK's future skills-based immigration system. Cm 9722.

https://assets.publishing.service.gov.uk/government/uploads/system/uploads/attac hment_data/file/766672/The-UKs-future-skills-based-immigration-systemaccessible-version.pdf

Horsley, T. (2017). Brexit and UK courts: awaiting fresh instruction. In M. Dougan (Ed.), The UK after Brexit. Legal and Policy Challenges (pp. 73-93). Intersentia. https://doiorg.ezproxy.lib.rmit.edu.au/10.1017/9781780685953

Jay, Z. (2017). Keeping rights at home: British conceptions of rights and compliance with the European Court of Human Rights. The British Journal of Politics and International Relations, 19(4), 842-860. https://doiorg.ezproxy.lib.rmit.edu.au/10.1177/1369148117732469

Joint Committee on Human Rights. (2016, December). The human rights implications of Brexit. House of Lords and House of Commons. https:/publications.parliament.uk/pa/jt201617/itselect/jtrights/695/695.pdf

Jones, O. (2020). With a Brexit deal that puts workers' rights at risk, we need unions more than ever. Guardian online. Opinion. https://www.theguardian.com/commentisfree/2020/dec/29/brexit-trade-dealworkers-rights-risk-unions

Levi, M. (1997). A Model, a Method, and a Map: Rational Choice in Comparative and Historical Analysis. In M.I. Lichbach, \& A.S. Zuckerman (Eds.), Comparative Politics: Rationality, Culture, and Structure (pp. 19-41). Cambridge University Press. https://ebookcentral.proquest.com

Lock, T. (2017, October 3). Human Rights Law in the UK after Brexit. Research Paper no. 2017/17. University of Edinburgh School of Law. https://papers.ssrn.com/sol3/papers.cfm?abstract_id=3046554 
Lock, T., Boyle, K., Greene, A., Harvey, D., Jancic, D., Kramer, A., McCall-Smith, K., Miller, N., O'Connor, N., Pritchard, H., Pues, A., Shields, K., Yong, A. \& Zahn, R. (2019). Brexit, Rights and Devolution. The Brexit and Rights Engagement Network. https://openaccess.city.ac.uk/id/eprint/22266/1/SSRN-id3321685.pdf

Lord, C. (2019). Integration through Differentiation and Segmentation: The Case of One Member State from 1950 to Brexit (and Beyond). In J. Batora, \& J.E. Fossum (Eds.), Towards a Segmented European Political Order: The European Union's Post-Crises Conundrum (pp. 289-313). Routledge.

March, J.G., \& Olsen, J.P. (1989). Rediscovering Institutions. Free Press.

March, J.G., \& Olsen, J.P. (2006). Elaborating the 'New Institutionalism'. In R.A.W. Rhodes, S.A. Binder, \& B.A. Rockman (Eds.), The Oxford Handbook of Political Institutions (pp. 3-20). Oxford University Press.

McColgan, A. (2016). The Implications and Consequences of UK Exit from the EU: Social Policies. In P. Birkinshaw, \& A. Biondi (Eds.), Britain Alone! (pp. 215-231). Wolters Kluwer.

McDonald, H. (2015, May 12). Scrapping Human Rights Act 'would breach Good Friday agreement'. Guardian online. https://www.theguardian.com/uknews/2015/may/12/scrapping-human-rights-act-would-breach-good-fridayagreement

Menon, A. (2020, December 31). Brexit is far from done - this deal is no 'game, set and match'. Guardian online. https://www.theguardian.com/commentisfree/2020/dec/30/brexit-far-from-done

Middleton, J. (2021, January 15). 48-hour week could be scrapped under 'plans to rip up worker protections' after Brexit. The Independent. https://www.independent.co.uk/news/uk/politics/brexit-workers-rights-eub1787603.html

Morales, A. (2021, January 15). After Brexit, UK seeks worker-rights reforms, setting up EU clash. Aljazeera. https://www.aljazeera.com/economy/2021/1/15/bbafterbrexitukseeks-worker-rights-reforms-setting-up-eu-clash

Morris, M. (2020, December 27). The agreement on the future relationship: a first analysis. Institute for Public Policy Research.

https://www.ippr.org/research/publications/the-brexit-eu-uk-trade-deal-a-firstanalysis

Moyer-Lee, K. (2021, January 9). Brexit gives the Tories a free hand to dismantle workers' rights. Aljazeera. Opinions. https://www.aljazeera.com/opinions/2021/1/9/brexitdeal-tories-uk-workers-rights

Neuberger D. (2014, February 12). The British and Europe. Cambridge Freshfields Annual Lecture. https://www.supremecourt.uk/docs/speech-140212.pdf

O'Cinneide, C. (2016, July 29). Equality rights in a post-Brexit United Kingdom. Bright Blue blog. https://humanrights.brightblue.org.uk/blog-1/2016/7/29/equality-rights-in-apost-brexit-united-kingdom

O'Cinneide, C. (2018, February). Brexit and Human Rights. Paper No. 16. Centre for International Governance Innovation. https://www.cigionline.org/publications/brexit-and-human-rights 
Patrick, A. (2016, October). Mapping the Great Repeal. Background Paper for the Thomas Paine Initiative. https://www.ariadne-network.eu/wpcontent/uploads/2015/03/Mapping-the-Great-Repeal-Thomas-Paine-InitiativeNovember-2016.pdf

Rogers, I. (2018, October 10). Brexit as a Revolution. Lecture at Trinity College, Cambridge. https://news.liverpool.ac.uk/2018/12/13/full-speech-sir-ivan-rogers-on-brexit/

Sargeant, J., Stojanovic, A., Etherington, H., \& Kane, J. (2020, May). Implementing Brexit. The Northern Ireland Protocol. Institute for Government. https://www.instituteforgovernment.org.uk/sites/default/files/publications/implem enting-brexit-northern-ireland-protocol.pdf

UK Cabinet Office. (2020, December). The Northern Ireland Protocol. https://assets.publishing.service.gov.uk/government/uploads/system/uploads/attac hment data/file/950601/Northern Ireland Protocol - Command Paper.pdf

UK Department for Exiting the European Union. (2017, July 13). EU (Withdrawal) Bill. Factsheet 6: EU Charter of Fundamental Rights.

https://assets.publishing.service.gov.uk/government/uploads/system/uploads/attac $\underline{\text { hment data/file/714377/6.pdf }}$

UK Ministry of Justice. (2020, July 31). Government launches independent panel to look at judicial review. Press release. UK Ministry of Justice.

https://www.gov.uk/government/news/government-launches-independent-panel-tolook-at-judicial-review

Weale, A. (2018). Brexit and the improvised constitution. In B. Martill, \& U. Staiger (Eds.), Brexit and Beyond (pp. 28-36). UCL Press. https://doi.org/10.14324/111.9781787352759

Yong, A. (2017). Forgetting Human Rights - The Brexit Debate. European Human Rights Law Review, 5, 469-479. https://uk.westlaw.com/Document/IDF797430AE8D11E7AACE93A1608DA6E9/Vie w/FullText.html 